\title{
HUBUNGAN SELF-EFFICACY DENGAN TINGKAT KEPATUHAN MINUM OBAT PADA PENDERITA HIPERTENSI
}

\author{
Yovia Mardiana Kendu ${ }^{1}$, Abdul Qodir ${ }^{2 *}$, Frengki Apryanto ${ }^{3}$ \\ 1,2,3 STIKES Widyagama Husada Malang
}

*Corresponding author:

Abdul Qodir

STIKES Widyagama Husada Malang

Email: : abdulqodir@widyagamahusada.ac.id

\begin{abstract}
Emergency nursing services include services for emergency patients who are suddenly in a critical state and life threatening situation. The response time by nurses in nursing actions will affect the level of family satisfaction of patients in the Emergency Room (ER). To fird out the literature review of the relationship between nurse response time and family satisfaction of patients in the Emergency Room (ER). This study used Systematic Literature Reviews (SLR), with keywords in 2 languages, namely English and Indonesian. The data used in 10 journals were obtained from the results of screening a number of journals from international journal portal, ScienceDirect, and Google Scholar. From the overall results of 10 journals, it shows that the response time of nurses is in the fast category, there is a patient's family satisfaction with the satisfied category. With this, there is a Correlation of the nurse's response time and the patient's family satisfaction. There is a Correlation of nurse response time and family satisfaction

Keywords : nurse response time; patient's family satisfactio; emergency department.
\end{abstract}

\begin{abstract}
Abstrak
Ketidakpatuhan dalam mengkonsumsi obat hipertensi merupakan masalah yang dapat menyebabkan tekanan darah tidak terkontrol. Self-efficacy atau keyakinan diri pada seseorang dapat menjadi faktor penentu untuk meningkatkan kemampuan dalam mengubah perilaku seseorang. Untuk mengetahui hubungan self-efficacy dengan tingkat kepatuhan minum obat pada penderita hipertensi. Penelitian ini menggunakan metode pendekatan cross sectional dengan jumlah sampel penelitian 84 responden. Teknik pengambilan sampelnya menggunakan purposive sampling. Instrumen penelitian yang digunakan adalah kuesioner MASE-R untuk mengukur selfefficacy dan kuesioner MMAS-8 untuk mengukur kepatuhan minum obat. Hasil penelitian dianalisis menggunakan uji chi-square. Hasil peneliti ini, dari 84 responden, sejumlah 48 (57.1\%) responden menunjukkan self-efficacy tinggi dan 36 (42.9\%) orang yang mempunyai self-efficacy rendah. Untuk kepatuhan minum obat, 32 (38.1\%) responden masuk pada kategori patuh tinggi sedangkan patuh sedang $32(38.1 \%)$ responden dan patuh rendah dengan jumlah $20(23.8 \%)$ responden. Berdasarkan hasil uji statistik menggunakan chi square diperoleh nilai p 0.000 yang berarti nilai $p 0.000<p 0.05$. Terdapat hubungan yang signifikan antara self-efficacy dengan tingkat kepatuhan minum obat pada penderita hipertensi di Puskesmas Dinoyo Kota Malang. Pasien hipertensi yang mempunyai self efficacy tinggi berkorelasi dengan patuh menjalankan terapi obat anti hipertensi.
\end{abstract}

Kata Kunci: Self-efficacy; Kepatuhan Minum Obat; Hipertensi. 


\section{PENDAHULUAN}

Hipertensi merupakan salah satu masalah kesehatan yang berkembang setiap tahun, hal ini menjadi perhatian di negara maju maupun di negara berkembang. Menurut World Health Organization (WHO) pada tahun 2015 jumlah kasus hipertensi di dunia sekitar 1,13 milliar, kemudian diperkirakan pada tahun 2025 prevalensi penderita hipertensi berkisar sekitar 1,5 miliar dan diperkirakan setiap tahunnya terdapat 9,4 juta orang meninggal akibat komplikasi dari hipertensi (Kawulusan et al., 2019).

Di Indonesia jumlah penderita hipertensi yaitu berkisar sekitar 63.309.620 kasus berdasarkan hasil pengukuran darah pada penduduk yang berusia $\geq 18$ tahun. Jumlah penderita hipertensi di Jawa Timur pada tahun 2013 sebesar 26,3\% dan terjadi peningkatan di tahun 2018 dengan jumlah penderita hipertensi sebesar 36,32\%, (Riskesdas, 2018). Khusus di kota Malang jumlah penderita hipertensi pada tahun 2014 berkisar sekitar 50.612 (Dinkes Kota Malang, 2014). Hipertensi terjadi pada kelompok umur 31-44 tahun sebanyak 31,6\%, umur 45-54 tahun sebanyak 45,3\%, umur 55-64 tahun sebanyak $55,2 \%$ dan terjadi peningkatan di tahun 2019 dengan jumlah penderita hipertensi mencapai 60.358 orang.

Menurut Dinas Kesehatan Kota Malang tahun 2019 prevelensi tertinggi hipertensi yaitu di Puskesmas Dinoyo Kota Malang. Berdasarkan studi pendahuluan yang dilakukan oleh peneliti pada bulan Februari 2020 di Puskesmas Dinoyo Kota Malang didapatkan sebanyak 2877 kunjungan penderita hipertensi setiap tahun di Puskesmas Dinoyo Kota Malang.

Penyakit ini bila tidak diobati atau tidak patuh minum obat dapat menimbulkan komplikasi berbahaya hingga berakibat fatal. Menurut penelitian Ma et al., (2013), mengatakan bahwa ketidakpatuhan merupakan hal yang dapat membuat terapi berpotensi untuk gagal, hal tersebut dapat mengakibatkan komplikasi serta organ tubuh bisa menjadi rusak. Hal ini dapat menjadi penyebab utama terjadinya penyakit jantung koroner, stroke, gagal jantung kongestif, dan penyakit ginjal stadium akhir, dan lainnya.

Prevalensi ketidakpatuhan terhadap pengobatan di Amerika Serikat menunjukan sebanyak setengah dari 187 juta pasien hipertensi di Amerika Serikat tidak minum obat sesuai resep (American Heart Association), (Kawulusan et al., 2019). Di Indonesia tingkat kepatuhan berobat dan tingkat kepatuhan kontrol pada pasien hipertensi cukup rendah yaitu tidak sampai 50\% (Amira et al., 2018). Menurut Riskesdas, (2018), jumlah penderita hipertensi yang tidak rutin minum obat sebesar $32,3 \%$ sedangkan yang tidak minum obat antihipertensi berjumlah $13,3 \%$.

Keberhasilan pengobatan pada penderita hipertensi dipengaruhi oleh beberapa faktor, salah satunya adalah kepatuhan dalam mengomsumsi obat, sehingga pasien hipertensi dapat mengendalikan tekanan darah dalam batas normal. Faktor-faktor yang mempengaruhi kepatuhan minum obat yaitu usia, jenis kelamin, pengetahuan, tingkat pendidikan, keyakinan, pekerjaan, motivasi, dukungan keluarga, dukungan tenaga kesehatan, (Amira, et al., 2018). Sedangkan menurut penelitian (Kawulusan et al., 2019) mengatakan bahwa faktor yang mempengaruhi kepatuhan minum obat salah satunya ialah faktor pasien itu sendiri.

Keyakinan pasien terhadap sesuatu bahwa pengobatan akan memberikan efek samping yang dirasa mengganggu, khawatir tentang efek jangka panjang serta ketergantungan terhadap pengobatan berpengaruh terhadap kepatuhan pasien menurut Kawulusan et al., (2019). Hal tersebut sejalan dengan teori kognitif sosial (social cognitive theory) yang dikemukakan Bandura yang menyatakan bahwa self-efficacy (keyakinan diri) berhubungan dengan perubahan perilaku seseorang (Behavioural Change). 
Self-efficacy memberikan kontribusi terhadap pemahaman yang lebih baik dalam proses perubahan perilaku. Self-efficacy yang tinggi akan menganggap bahwa dirinya mampu menggunakan kemampuan untuk mencapai suatu hasil yang baik sesuai dengan apa yang diharapkan (Amila et al., 2018), hal ini sejalan dengan penelitian (Kawulusan et al., 2019) yang mengatakan bahwa penderita hipertensi dengan selfefficacy yang tinggi mempunyai peluang 11 kali menunjukan kepatuhan minum obat yang baik dibandingkan dengan pasien yang memiliki self-efficacy rendah. Tujuan penelitian ini adalah untuk mengetahui hubungan self-efficacy dengan tingkat kepatuhan minum obat pada penderita hipertensi.

\section{METODE}

Penelitian ini menggunakan metode kuantitatif dengan desain penelitian cross sectional. Desain penelitian ini digunakan untuk mengetahui hubungan antara self-efficacy merupakan variabel independent dan tingkat kepatuhan minum obat hipertensi merupakan variabel dependen (Notoadmojo 2012). Jumlah sampel yang telah didapatkan 84 partisipan di Puskesamas Dinoyo Kota Malang. Teknik pengambilan sampel menggunakan purposive sampling.

Pasien hipertensi yang dapat menjadi subyek penelitian adalah yang memenuhi kriteria inklusi yaitu, Responden berusia 18-65 tahun, Pasien hipertensi yang berobat di Puskesmas Dinoyo Kota Malang dan menjalani terapi pengobatan hipertensi minimal 2 bulan, sedangkan kriteria eksklusi pada penelitian ini adalah Penderita hipertensi dengan komplikasi seperti gagal ginjal kronis, penyakit jantung coroner, dan diabetes mellitus.

Instrument penelitian digunakan untuk mengukur nilai variabel yang diteliti. Dalam penelitian ini menggunakan dua instrument yaitu kuisioner selfefficacy. Kuisioner yang digunakan dari MASES-R dalam bentuk bahasa Inggris dan di translate oleh ahli bahasa Inggris di Laboratarium Bahasa Inggris kampus STIKES Widyagama Husada Malang. Kuisioner tersebut sudah valid dengan nilai rehabilitasnya 0,95 dan sudah di gunakan di Indonesia Oleh (Misgiarti \& Ervina 2015) dan (Kawulusun et al., 2019) dan kuisioner kepatuhan minum obat menggunakan kuisioner dari MMAS-8. Kuisioner tersebut sudah valid dengan nilai rehabilitasnya 0,764 (Rayno Dan Chayne, 2018). Uji hipotesis untuk menganalisis hubungan self-efficacy dengan tingkat kepatuhan minum obat pada penderita hipertensi menggunakan uji chi-square.

\section{HASIL DAN PEMBAHASAN}

Hasil penelitian menunjukan bahwa sebagian besar responden berjenis kelamin perempuan $52(61,9 \%)$ dibandingkan laki-laki $32(38,1 \%)$ seperti pada tabel 1 . Hal ini sejalan dengan penelitian sebelumnya oleh Sundari L \& Bangsawan M (2015) dengan hasil penelitian perempuan lebih banyak terkena hipertensi dibandingkan laki-laki, teori yang di kemukan oleh Yundini (2006) juga mengatakan bahwa Perempuan lebih banyak yang menderita hipertensi dibandingkan laki-laki yang di akibatkan oleh faktor hormonal.

Perempuan lebih banyak menderita hipertensi dibandingkan laki-laki terutama pada penderita hipertensi dewasa dan lansia. Sebelum memasuki masa menopouse, perempuan mulai kehilangan hormon estrogen sedikit demi sedikit dan sampai masanya hormon estrogen harus mengalami perubahan seiring dengan bertambahnya usia. Berdasarkan hasil penelitian, didapatkan data bahwa 39 (46,4\%) penderita hipertensi berusia 56-65 tahun yang berarti sebagian besar penderita hipertensi berjenis kelamin perempuan sudah mengalami menopause.

Perempuan menopause memiliki pengaruh lebih besar terhadap kejadian hipertensi. Perempuan dengan menopause akan mengalami perubahan hormonal. Fungsi estrogen adalah sebagai vasodilator pembuluh darah, apabila terjadi penurunan dari sekresi estrogen akan mengakibatkan penyempitan pembuluh darah 
(vasokonstriksi) yang dapat menyebabkan tekanan darah meningkat.

Tabel 1. Karakteristik Responden

\begin{tabular}{|c|c|c|}
\hline Variabel & $\begin{array}{c}\text { Jumlah } \\
\text { (n) }\end{array}$ & $\begin{array}{c}\text { Prosentase } \\
(\%)\end{array}$ \\
\hline \multicolumn{3}{|l|}{ Jenis Kelamin } \\
\hline Laki-laki & 32 & 38.1 \\
\hline Perempuan & 52 & 61.9 \\
\hline \multicolumn{3}{|l|}{ Usia } \\
\hline $18-25$ & 5 & 6.0 \\
\hline $26-35$ & 7 & 8.3 \\
\hline $36-45$ & 13 & 15.5 \\
\hline $46-55$ & 20 & 23.8 \\
\hline $56-65$ & 39 & 46.4 \\
\hline \multicolumn{3}{|l|}{ Pendidikan } \\
\hline SD & 8 & 9.5 \\
\hline SMP & 28 & 33.3 \\
\hline SMA & 32 & 38.1 \\
\hline Perguruan Tinggi & 16 & 19.0 \\
\hline \multicolumn{3}{|l|}{ Pekerjaan } \\
\hline Tidak bekerja & 19 & 22.6 \\
\hline Buruh & 5 & 6.0 \\
\hline Pelajar/mahasiswa & 2 & 2.4 \\
\hline wiraswasta & 41 & 48.8 \\
\hline Dan lain-lain & 17 & 20.2 \\
\hline \multicolumn{3}{|l|}{ Tekanan Darah } \\
\hline Hipertensi Derajat 1 & 34 & 40.5 \\
\hline Hipertensi Derajat II & 50 & 59.5 \\
\hline \multicolumn{3}{|l|}{ Lama Pengobatan } \\
\hline 2-6 Bulan & 28 & 33.3 \\
\hline 7-11 Bulan & 24 & 28.6 \\
\hline 1-5 Tahun & 30 & 35.7 \\
\hline 6-9 Tahun & 2 & 2.4 \\
\hline \multicolumn{3}{|l|}{ SELF-EFFICACY } \\
\hline Tinggi & 48 & 57.1 \\
\hline Rendah & 36 & 42.9 \\
\hline \multicolumn{3}{|c|}{ Kepatuhan Minum Obat } \\
\hline Patuh Tinggi & 32 & 38.1 \\
\hline Patuh sedang & 32 & 38.1 \\
\hline Patuh Rendah & 20 & 23.8 \\
\hline
\end{tabular}

Hasil penelitian menunjukan bahwa usia 56-65 tahun lebih tinggi, dengan hal ini berbeda dengan penelitian sebelumnya oleh Anggara (2013) yang mendapatkan hasil penelitian bahwa penderita hipertensi paling tinggi ditemukan pada kelompok usia $>65$ tahun. Menurut Anggara \& Prayitno (2013) mengatakan bahwa semakin bertambahnya usia maka akan terjadi perubahan fisiologis pada seseorang.

Individu yang berusia 56-65 tahun akan mengalami suatu kondisi dimana pada dinding pembuluh darah akan kehilangan elastisitas. Hal ini terjadi karena pada usia tersebut arteri kehilangan kelenturannya dan menjadi kaku karena itu darah pada setiap denyut jantung dipaksa untuk melalui pembuluh darah yang sempit daripada biasanya dan menyebabkan naiknya tekanan darah.
Hasil penelitian menunjukan bahwa sebagian besar responden berpendidikan SMA dengan hal ini semakin tinggi pendidikan seseorang maka pengetahuan akan semakin baik. Menurut Adrian K. M (2013) mengatakan bahwa pendidikan merupakan salah satu aspek penting dalam peningkatan pengetahuan pada individu. hal tersebut sejalan dengan penelitian yang dilakukan oleh Qodir (2020) bahwa pasien hipertensi yang memiliki tingkat Pendidikan tinggi bekorlasi dengan kepatuhan yang baik dalam menjalankan terapi hipertensi dalam hal modifikasi gaya hidup.

Menurut Azwar di dalam Nirwana (2011), semakin seseorang berpendidikan, maka pemahaman akan sesuatu yang baik dan buruk dapat menentukan sistem kepercayaan sehingga konsep tersebut ikut berperan dalam menentukan sikap dan perilaku seseorang dalam suatu hal. Sehingga dengan pendidikan yang tinggi, perilaku responden juga tinggi dalam mengontrol factor risiko penyakit hipertensi.

Tingkat pendidikan yang tinggi akan berpengaruh terhadap perubahan perilaku pada individu, sehingga dengan hal ini semakin tinggi pendidikan individu maka akan semakin mudah menerima informasi dan mempunyai banyak pengetahuan yang dimilikinya , sehingga individu semakin baik dalam melakukan tindakan dan perilaku dalam mengonsumsi obat hipertensi.

Hasil penelitian menunjukan bahwa sebagian besar responden pekerjaannya sebagai wiraswasta hal ini sejalan dengan penelitian Agriani (2015) yang mendapatkan hasil yang lebih dominan yaitu bekerja sebagai wiraswasta. Penyakit hipertensi di pengaruhi oleh beberapa faktor salah satunya yaitu pekerjaan pada seseorang (Malara, 2014).

Seseorang yang mempunyai pekerjaan akan lebih menghabiskan waktunya di pekerjaan sehingga mereka lalai dalam menjaga kesehatan dan pola ativitasnya. Seseorang dengan pola aktivitas kurang baik akan lebih rentan terhadap peningkatan tekanan darah. 
Hasil penelitian menunjukan bahwa sebagian besar responden mempunyai riwayat hipertensi derajat 2 dengan jumlah 50 (59.5\%) orang. Sedangkan responden dengan jumlah minimal yaitu responden dengan riwayat hipertensi derajat 1 dengan jumlah 34 (40,5\%) orang. Namun hal ini berbeda dengan penelitian yang di lakukan oleh Devi A. S.I \& Aryani P (2015) yang mengatakan bahwa responden yang mempunyai derajat hipertensi 1 lebih tinggi dengan jumlah $57.8 \%$ di bandingkan dengan hipertensi derajat 2 .

Menurut Norhidayah A. S \& Relawati A mengatakan bahwa penderita hipertensi dengan peningkatan tekanan darah terjadi karena pola hidup yang kurang baik. Seseorang dengan peningkatan tekanan darah derajat 2 terjadi karena kurang aktivitas fisik dan tidak menjaga pola makan.

Hasil penelitian menunjukan bahwa sebagian besar responden lama menjalani pengobatan hipertensi mulai dari 1-5 tahun dengan jumlah $35.7 \%$. Hal ini berbeda dengan penelitian yang di lakukan oleh Bilqis Siti (2018) yang mengatakan bahwa sebagian besar responden yang lama menjalani pengobatan yaitu $<2$ tahun dengan jumlah $82.8 \%$.

Semakin lama penderita hipertensi menjalani pengobatan maka pengalaman dan pengetahuan tentang pengobatan hipertensi akan semakin baik. Menurut Pujasari A (2015) mengatakan bahwa faktor yang mempengaruhi kepatuhan minum obat pada penderita salah satunya yaitu lama pengobatan.

Menurut Ramadona (2011) menjelaskan bahwa pasien yang telah mengalami hipertensi selama 1-5 tahun cenderung lebih mematuhi proses dalam mengonsumsi obat karena adanya rasa ingin tau yang besar dan keinginan untuk sembuh, sedangkan dengan pasien yang telah mengalami hipertensi lebih $>5$ tahun memiliki kecenderungan kepatuhan mengonsumsi obat yang buruk. Hal ini terjadi karena faktor kejenuhan pada penderita hipertensi yang sudah lama menjalani pengobatan hipertensi.
Seseorang yang lama menjalani pengobatan hipertensi maka akan semakin terbentuk sikap individu terhadap perubahan perilaku sehingga dengan hal ini berpengaruh terhadap perilaku seseorang seseorang dalam mengonsumsi obat hipertensi.

Tabel 2. Hasil analisis Self-efficacy dengan kepatuhan minum obat

\begin{tabular}{|c|c|c|c|c|c|c|c|}
\hline \multirow{3}{*}{ Self-efficacy } & \multicolumn{6}{|c|}{ Kepatuhan Minum Obat } & \multirow{3}{*}{$\begin{array}{c}\text { Nilai } \\
p\end{array}$} \\
\hline & \multicolumn{3}{|c|}{$\begin{array}{l}\text { Patuh } \\
\text { Tinggi }\end{array}$} & $\begin{array}{c}\text { Patuh } \\
\text { Sedang }\end{array}$ & \multicolumn{2}{|c|}{$\begin{array}{l}\text { Patuh } \\
\text { Rendah }\end{array}$} & \\
\hline & $\mathrm{n}$ & $\%$ & $\mathrm{n}$ & $\%$ & $\mathrm{n}$ & $\%$ & \\
\hline Tinggi & 29 & $60.4 \%$ & 15 & $31.2 \%$ & 4 & $8.3 \%$ & \multirow{3}{*}{0.000} \\
\hline Rendah & 3 & $8.3 \%$ & 17 & $47.2 \%$ & 16 & $44.4 \%$ & \\
\hline Total & 32 & $8.1 \%$ & 32 & $38.1 \%$ & 20 & $23.8 \%$ & \\
\hline
\end{tabular}

Hasil penelitian didapatkan responden dengan kategori tingkat self-efficacy yang tinggi dengan jumlah $48 \quad(57.1 \%)$ orang. Sedangkan responden yang mempunyai kategori rendah yaitu dengan jumlah 36 (42.9\%) orang. Hal ini sejalan dengan penelitian yang dilakukan oleh Kawulusan B K et all., (2019) yang mengatakan bahwa sebagian besar responden mempunyai self-efficacy yang tinggi yaitu 77,6\%. Dalam penelitian tersebut di jelaskan bahwa responden yang mempunyai self-efficacy yang tinggi yaitu penderita yang pernah mengalami kekambuhan terhadap penyakit saat penderita tidak menjalankan pengobatan hipertensi yang dianjurkan oleh tenaga medis, hal ini juga sejalan dengan teori Bandura (2006) yang mengatakan faktor-faktor yang mempengaruhi self-efficacy yaitu faktor Pengalaman pada seseorang.

Penelitian yang dilakukan Amelia (2018) mendapatkan hasil yang serupa dengan jumlah responden yang mempunyai self-efficacy yang tinggi yaitu 96.9\%. dalam penelitian tersebut mengatakan bahwa self-efficacy akan memberikan kontribusi terhadap pemahaman yang lebih baik dalam proses perubahan perilaku kesehatan.

Seseorang yang mempunyai self-efficacy yang tinggi akan mempunyai kemampuan untuk memotivasi dirinya untuk melakukan perilaku yang bertujuan berdasarkan atas aktivitas kognitifnya, sehingga kemampuan kognitif 
pada seseorang akan membentuk kemampuan untuk memahami faktor-faktor yang mempengaruhi kesehatannya dan menggunakan kemampuan dirinya untuk memelihara kondisi kesehatannya. Self-efficacy dipengaruhi oleh beberapa faktor yaitu salah satunya faktor pengalaman yang pernah di alami oleh seseorang. Pengalaman terhadap kekambuhan penyakit hipertensi tersebut merupakan suatu kegagalan yang dijadikan sabagai bahan evaluasi bahwa kekambuhan pada penyakit hipertensi tersebut merupakan perilaku tidak patuh dalam mengonsumsi obat hipertensi.

Hal tersebut dapat membuat penderita hipertensi yakin bahwa dengan menjalankan pengobatan hipertensi yang dianjurkan oleh tenaga medis penderita dapat terhindar dari resiko kekambuhan penyakit hipertensi. Sehingga mendorong penderita patuh dalam mengonsumsi obat hipertensi.

Hasil penelitian didapatkan responden dengan kategori kepatuhan minum obat yang tinggi yaitu dengan jumlah 32 (38.1\%) dan kepatuhan sedang sebanyak 32 (38.1\%) orang, sedangkan responden dengan kategori minimal yaitu dengan kategori rendah sebanyak 20 (23.8\%) orang. Hal ini berbeda dengan penelitian yang dilakukan oleh Sinuraya K. R., et all (2018) dengan hasil penelitian kategori patuh tinggi 14,2\%, sedang (32,2\%), dan rendah $(53,5 \%)$ dalam penelitiannya menyimpulkan faktor yang mempengaruhi kepatuhan minum obat pada penderita hipertensi yaitu, gender, tingkat pendidikan, pekerjaan, riwayat keluarga, kejadian komplikasi dan pengalaman mendapatkan informasi.

Menurut WHO (2015) mengatakan bahwa faktor yang mempengaruhi perilaku kepatuhan minum obat pada individu yaitu keyakinan diri pada individu. Keyakinan pasien terhadap pengobatan hiperetnsi yang dirasa mengganggu dan khawatir dari efek samping dari obat dan ketergantungan pada obat hipertensi. Hal ini akan menentukan sikap dan perilaku atau tindakan seseorang berdasarkan keyakinan yang dimiliki oleh masing-masing individu.
Penelitian ini menunjukan bahwa responden di Puskesmas Dinoyo Kota Malang memilki persepsi dan keyakinan diri yang baik tentang penyakit hipertensi yang dialaminya dan tentang pengobatan hipertensi, bahwa mereka yakin dengan menjalani pengobatan hipertensi sesuai dengan anjuran tenaga medis mereka tidak akan mengalami kekambuhan penyakit hipertensi. Hal ini dapat dilihat melalui jawaban responden di kuisioner yang menjawab bahwa mereka selalu minum obat, tidak berhenti minum obat walaupun keadaan sudah membaik, tidak mengurangi dosis obat, tidak menghentikan pengobatan tanpa instruksi dari dokter. Sehingga peneliti menyimpulkan bahwa keyakinan diri mempunyai pengaruh pada kepatuhan minum obat pada penderita hipertensi.

Dalam penelitian ini menunjukan bahwa ada pengaruh yang signifikan antara self-efficacy dengan tingkat kepatuhan minum obat pada penderita hipertensi di Puskesmas Dinoyo Kota Malang. Hal ini sejalan dengan penelitian yang dilakukan oleh Mustafa K (2018) yang mengatakan bahwa ada hubungan yang signifikan antara self-efficacy dengan tingkat kepatuhan minum obat pada penderita hipertensi.

Self-efficacy merupakan salah satu faktor kunci dalam pelaksanaan kontrol pribadi, termasuk kontrol atas keadaan kesehatan sendiri (Sedjati, 2013). Hal ini juga sejalan dengan teori yang dikemukakan oleh Bandura bahwa efikasi diri mempengaruhi perilaku pada diri manusia. Self-efficacy akan memberikan dampak terhadap bagaimana individu merasakan, berpikir, memotivasi diri dan berperilaku (Zlatanovic \& Jerusalem,M., 2016). Self-efficacy akan mempengaruhi sejauh mana pasien akan berusaha dan sejauh mana pasien tetap kuat dalam menghadapi masalah. Selfefficacy juga akan menentukan perubahan perilaku pada seseorang dan menentukan apakah perubahan perilaku kesehatan akan dimulai, berapa banyak usaha yang akan dikeluarkan, dan berapa lama akan dipertahankan dalam 
menghadapi rintangan serta kegagalan (Schwarzer, 2012).

Seseorang dengan self-efficacy yang tinggi akan menganggap kegagalan sebagai suatu pengalaman yang dianggap sebagai kegagalan yang terjadi karena kurangnya usaha. Menurut Kawulusan et all (2019) mengatakan bahwa seseorang yang mempunyai selfefficacy yang tinggi adalah orang yang berkinerja sangat baik dalam mengerjakan tugas tertentu, sekalipun tugas tersebut adalah tugas yang sulit, individu tersebut tidak memandang tugas sebagai suatu ancaman yang harus dihindari.

Menurut Amila (2018) mengatakan bahwa ada beberapa faktor yang mempengaruhi kepatuhan minum obat pada penderita hipertensi selain dari keyakinan diri pada individu yaitu pendidikan, pengetahuan, motivasi, dukungan keluarga. Sedangkan menurut WHO (2015) juga mengatakan faktor yang mempengaruhi kepatuhan minum obat yaitu sumber daya, sikap, pengetahuan, persepsi dan kurangnya sistem distribusi obat.

Faktor yang mempengaruhi kepatuhan minum obat yaitu keyakinan diri pada pasien itu sendiri, keyakinan diri yang dimimilki individu tentang efek samping dari pengobatan hipertensi yang dirasa mengganggu dan kekhawatiran pasien terhadap ketergantung pada pengobatan hipertensi, sehingga dengan hal ini selfefficacy sangat ada hubungannya dengan kepatuhan minum obat pada penderita hipertensi.

Individu yang mempunyai self-efficacy yang tinggi akan mengangap dirinya mampu untuk melakukan sesuatu hal yang ingin dicapai sama halnya dengan patuh dalam mengonsumsi obat, dengan mempunyai keyakinan seseorang akan termotivasi dan meningkatkan harapan individu untuk sembuh dan akhirnya individu akan terdorong untuk patuh dalam mengonsumsi obat hipertensi.

Pada peneltian menggunakan kuesioner yang sudah terstandar dan sudah melalui uji validitas dan reliabilitas, hal tersebut merupakan kelbihan dari penelitian ini, akan tetapi peneliti menyadari bahwa tidak dapat mengontrol variabel-variabel yang dapat mempengaruhi kepatuhan terapi obat anti hipertensi pada pasien hipertensi.

\section{KESIMPULAN}

Terdapat hubungan antara self-efficacy dengan tingkat kepatuhan minum obat pada penderita hipertensi di Puskesams Dinoyo Kota Malang. Seseorang yang mempunyai self-efficacy yang tingggi akan mempunyai perilaku dalam mengonsumsi obat hipertensi yang lebih tinggi dibandingkan dengan yang mempunyai selfefficacy yang rendah. Mayoritas kepatuhan minum obat pada penderita hipertensi di Puskesmas Dinoyo Kota Malang menunjukan patuh tinggi dan juga patuh sedang.

\section{UCAPAN TERIMA KASIH}

Terima kasih dan penghargaan saya sampaikan pula kepada yang terhormat Puskesmas Dinoyo Kota Malang yang telah memberikan ijin untuk lokasi penelitian dan seluruh responden penelitian yang telah berpartisipasi dalam penelitian ini.

\section{DAFTAR RUJUKAN}

Al-Noumani, H., Wu, J. R., Barksdale, D., Sherwood, G., AlKhasawneh, E., \& Knafl, G. (2019). Health beliefs and medication adherence in patients with hypertension: A systematic review of quantitative studies. Patient Education andCounseling,102(6), 1045-1056.

https://doi.org/10.1016/j.pec.2019.02.022

Amila, A., Sinaga, J., \& Sembiring, E. (2018). SelfEfficacy dan Gaya Hidup Pasien Hipertensi. Jurnal Kesehatan, 9 (3), 360.

https://doi.org/10.26630/jk.v9i3.974

Anggraini, M. T. (2016).’Perbedaan Fungsi Keluarga Dan Kualitas Hidup Antara Mahasiswa Kedokteran Dan Non Kedokteran". Thesis.

Anggriani (2015). Angka kejadian dan Faktor risiko Hipertensi di Kota Palembang, Jurnal Kedokteran dan Kesehatan, Publikasi Ilmiah FK Unsri,JKK, 
2014 Th. 46, No. 1.

Ardian, I. (2018). Signifikansi Tingkat Stres Dengan Tekanan Darah Pada Pasien Hipertensi. Unissula Nursing Conference Call for Paper \& National Conference, 1 (1), 152-156.

https://doi.org/10.26532/.V1I1.2907.G2114

Bilqis, S. (2018). Hubungan Lama Sakit Dengan Kepatuhan Minum Obat Pada Pasien Hipertensi Di Dusun Depok Ambarketawang Gam[ping Slemen Yogyakarta.

Elvivin., Lestari, H., \& Ibrahim, K. (2015). Analisis Faktor Risiko Kebiasaan Mengkonsumsi Garam, Alkohol, Kebiasaan Merokok dan Minum Kopi Terhadap Kejadian Hipertensi pada Nelayan Suku Bajo di Pulau Tasipi Kabupaten Muna Barat Tahun 2015. Jurnal Ilmiah Mahasiswa Kesehatan Masyarakat, 1-12. Retrieved from https://media.neliti.com/.../185583-ID-analisisfaktor-risiko-kebiasa.

Flack, J. M., \& Adekola, B. (2019). Blood pressure and the new ACC/AHA hypertension guidelines. Trends in Cardiovascular Medicine, (xxxx). https://doi.org/10.1016/j.tcm.2019.05.003

Gita, S. Y. O., Delmi, S., \& Lestari, Y. (2015). Hubungan Merokok dengan Kejadian Hipertensi pada LakiLaki Usia 35-65 Tahun di Kota Padang. Yashinta OctavianGitaSetyanda,4(2),434-440.

Hasanah, M., Widodo, D., \& Widiani, E. (2016). Hubungan obesitas dengan hipertensi pada masyarakat di wilayah RW 13 Dusun Mojosari Desa Ngenep Kecamatan Karangploso. Nursing News: Jurnal Ilmiah Mahasiswa Keperawatan, $1(2), 35-44$.

Huang, Y. M., Shiyanbola, O. O., \& Chan, H. Y. (2018). A path model linking health literacy, medication self-efficacy, medication adherence, and glycemic control. Patient Education and Counseling, 101(11), 1906-1913.

https://doi.org/10.1016/j.pec.2018.06.010
Jayanti, I. G. A. N., Wiradnyani, N. K., \& Ariyasa, I. G. (2018). Hubungan pola konsumsi minuman beralkohol terhadap kejadian hipertensi pada tenaga kerja pariwisata di Kelurahan Legian. Jurnal Gizi Indonesia, 6(1), 65.

https://doi.org/10.14710/jgi.6.1.65-70

Katigbak, C., \& Fontenot, H. B. (2018). A Primer on the New Guideline for the Prevention, Detection, Evaluation, and Management of Hypertension. Nursing for Women's Health, 22(4), 346-354. https://doi.org/10.1016/j.nwh.2018.06.003

Kawulusan, K. B., Katuuk, M. E., \& Bataha, Y. B. (2019). Hubungan Self-Efficacy Dengan Kepatuhan Minum Obat Hipertensi Di Puskesmas Ranotana Weru Kota Manado. Jurnal Keperawatan, 7(1), 19.

Misgiarti dan Ervina A. (2015). Hubungan Tingkat Kepatuhan Minum Obat Pada Pasien Hipertensi di Poliklinik Jantung RSUD Dr. Saiful Anwar. Universitas Brawijaya Malang.

Mustafa K,. (2018). Hubungan Self-efficacy dengan Kepatuhan Minum obat Penderita Hipertensi di Puskesmas Kuta Alam Banda Aceh. Fak. Kedokteran Universitas Syiah Kuala Darussalam Banda Aceh.

Qodir, A. (2020). Analisis Faktor Determinan yang berhubungan dengan Kepatuhan Rekomendasi Modifikasi Gaya Hidup Pasien Hipertensi. Jurnal Ners Dan Kebidanan (Journal of Ners and Midwifery), 7(2), 256-263.

https://doi.org/10.26699/jnk.v7i2.art.p256-263

Riskesdas .(2018). Hasil Utama Riskesdas Kota Malang. Kementerian Kesehatan Republik Indonesia. (1-88).

Rano K,. Sinuraya,. Dika,. P,. Destiani,. Irma M,. Puapitasari,. \& Ajeng D,. (2018). Tingkat Kepatuhan Pengobatan Pasien Hipertensi di Fasilitas Kesehatan Tingkat Pertama di Kota Bandung. Jurnal Frmasi Klinik Indonesia, Juni 2018. Vol.7 No.2, hlm 124-133. http://ijcp.or.id. 
DOI: 10. 15416/ijcp.2018/7/2.124

Saad, A. M. J., Younes, Z. M. H., Ahmed, H., Brown, J. A., Al Owesie, R. M., \& Hassoun, A. A. K. (2018). Self-efficacy, self-care and glycemic control in Saudi Arabian patients with type 2 diabetes mellitus: A cross-sectional survey. Diabetes Research and Clinical Practice, 137, 28-36. https://doi.org/10.1016/j.diabres.2017.12.014

Sinuraya., K., R et all .(2018). Faktor-faktor Risiko Hipertensi Primer Di Puskesmas Tlogosari Kulon Kota Semarang. Jurnal Kesehatan Masyarakat, Volume 1, Nomor 2, Tahun 2018.

Sugiono .(2015). Desain Ukuran Sampel Penelitian Kuantitatif dan Kualitatif di Bidang Kesehatan : Gadjah Mada University Press.

Sukma A, N,. Widyajanarko B,. \& Riyanti. E. (2018).

Faktor Faktor Yang Berhubungan Dengan Kepatuhan Pasien Hipertensi Dalam Melakukan Terapi Di Puskesmas Pandanaran Kota Semarang. Jurnal Kesehatan Masyarakat (e-Jurnal), 6(5), 687-695.

Sylvestris, A. (2017). Hipertensi Dan Retinopati Hipertensi. Saintika Medika, 10(1), 1. https://doi.org/10.22219/sm.v10i1.4142

Wu, M. P., Wu, S. F. V., Lee, M. C., Peng, L. N., Tsao, L. I., \& Lee, W. J. (2019). Health-promotion interventions enhance and maintain self-efficacy for adults at cardiometabolic risk: $\mathrm{A}$ randomized controlled trial. Archives of Gerontology and Geriatrics, $\quad$ 82(365), 61-66. https://doi.org/10.1016/j.archger.2019.01.009

World Health Organization (WHO). 2015. "Q\&As on hypertension".http://www.who.int/features/qa/82/en /.

Yang, S., He, C., Zhang, X., Sun, K., Wu, S., Sun, X., \& Li, Y. (2016). Determinants of antihypertensive adherence among patients in Beijing: Application of the health belief model. Patient Education and Counseling, 99(11), 1894-1900. https://doi.org/10.1016/j.pec.2016.06.014

Yundini. (2016). Analisis Risiko Kejadian Hipertensi di Puskesmas Srondol Semarang Periode Bulan September-Oktoner 2011. Jurnal Penelitian Volume 1. Nomor 2 Tahun 2016 Semarang : Universitas Muhammadiyah Semarang.

Zlafonovic., \& Jerusalem, M. (2016). Generalized Self Efficacy scale. In J.Weinman, S. Wright, \& M. Johnston, Measures in health psychology: A user's portfolio. Causal and control beliefs (pp. 35-37). NFER-NELSON diperoleh dari http://www.drugsandalcohol.ie/26768/8/1/General_ SelfEfficacy_Scale\%20\%28GSE\%29.pdf 